\title{
Assessment of mental foramen position in dentate subjects
}

\author{
Dr. Jaafar Jasim Attar ${ }^{1^{*}}$, Dr. Siba Ahmed Mohmmed ${ }^{2 *}$ \\ 1-Specialist dentist in oral radiology at al-mahmodia specialized dental center, IRAQ \\ 2-Specialist dentist in oral histology at al-mahmodia specialized dental center, IRAQ \\ *Correspondent email:\{ jjadent2013@gmail.com, Aljrah1971@gmail.com\}
}

Submit: 15/4/2021 | Accepted: 11/6/2021 | Published:6/7/2021

\begin{abstract}
Mental foramen shares its significance in various fields of dentistry. Being a strategically eminent landmark, an understanding of the variation of its position is important. Aim: To evaluate frequently occurring position of mental foramen and its distance with reference to the lower premolars using panoramic image. Method: Total 215 panoramic image of patients taken for different diagnostic purpose, using Planmeca X-ray unit ProMax, The position of the mental foramen was recorded according to the categories which were put forward by Jasser and Nwoku. Result: The most common position was found to be between the two premolars approximately $60.5 \%$ for both gender, followed by below the second premolar approximately $34.9 \%$.conclusion: The most common location was reported to be between the two premolars, with a definite bilateral symmetry on both left and right sides. No gender preferences were observed.
\end{abstract}

Key words: Mental foramen, panoramic image, Position. 


\section{Introduction}

The mental foramen (MF) is a bilateral opening localized on an anterior surface of the mandible, The mental nerve a branch of the inferior alveolar nerve together with corresponding arteries and veins exit through the $\mathrm{MF}^{(1-}$ 2). The mental foramen is a funnel-like opening located on the surface of the anterolateral aspect of mandible ${ }^{(11)}$ The inferior alveolar nerve conducts unilaterally the sensory stimuli to the lower lip, labial mucosa, lower canine, and premolar, whereas blood vessels supply soft tissues of the lower jaw (3, 4). Successful and complication-free dental procedures such as curettage, root canal treatment, periapical surgery, orthognathic surgery, and effective anesthesia during nerve blocks depend on knowledge of an operator ${ }^{(5)}$.

An implant placement in an inter foramina area is strictly related to the location of the MF, because it determines a position of most distal implants. Many studies indicate that a minimum distance between MF

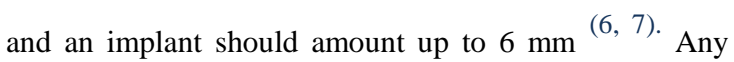
invasive procedure performed in this region may damage the neurovascular bundles and cause serious complications such as parenthesis ${ }^{(8)}$.

human skull, the mental foramen is regarded as a stable landmark on the mandible ${ }^{(10)}$.

The nerves and vessels transmitting through it provide sensory innervations and blood supply to important facial structures; these nerves are susceptible to injury during administration of local anesthesia and surgery Variation in the position of mental foramen is common, which can result in complications during surgical procedures (13-14).

In our retrospective study on the variability of mental foramen position using 215 digital panoramic image and to compare the results with those reported for other population.

\section{Material and Method}

Total 215 panoramic image of patients taken for different diagnostic purpose at Al_Mahmodia specialized dental center, and examined by two well-practiced examiner. The range age of the selected patients was between 18 - 45years old.

All of the sample matches the inclusion criteria which include the presence of minimum 22 teeth, including lower canine, premolars , and first molar, panoramic image with high resolution which clearly showed the mental foramen, and no pathological lesion in the area of interest Fig 1.

All panoramic image were taken by using Planmeca Xray unit ProMax 3D (tube potential:84 KV, tube current:16mA , exposure time:14.5S) Fig 2.

Long axes of the premolars served as the vertical references. The position of the mental foramen was recorded according to the categories which were put forward by Jasser and Nwoku [22], which were as follows:

Position 1: Anterior to the first premolar, Position 2: Below the first premolar, Position 3: Between the premolars, Position 4: Below the second premolar, Position 5: Posterior to the second premolar.

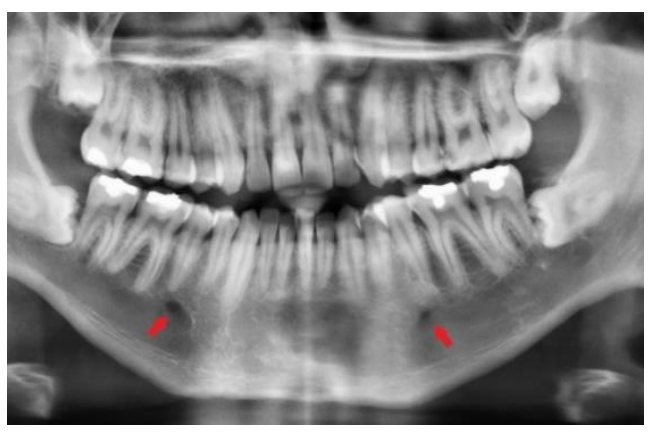

Fig 1 Mental foramen in panoramic radiograph 


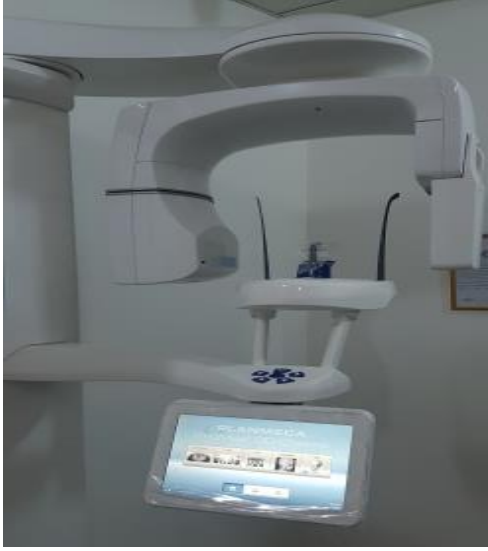

Fig 2 Planmeca X-ray unit

\section{Results and Discussion}

The 215 panoramic image which were evaluated, were grouped into those 99 male, and 116 female. The most common position was found to be between the two premolars position 3 approximately $60.5 \%$ for both gender, followed by the position 4 below the second premolar approximately $34.9 \%$.

(Table 1):Demonstrate means ,Std, median, for right and left MF positioning in both gender and total

\begin{tabular}{|c|c|c|c|}
\hline \multicolumn{2}{|l|}{ Gender } & \multirow{2}{*}{$\begin{array}{l}\text { right mental } \\
\text { foramen } \\
3.48 \\
\end{array}$} & \multirow{2}{*}{$\begin{array}{l}\text { left mental } \\
\text { foramen } \\
3.45\end{array}$} \\
\hline male & Mean & & \\
\hline & $\mathrm{N}$ & 99 & 99 \\
\hline & $\begin{array}{l}\text { Std. } \\
\text { Deviation }\end{array}$ & .629 & .627 \\
\hline & Median & 3.00 & 3.00 \\
\hline \multirow[t]{4}{*}{ female } & Mean & 3.31 & 3.35 \\
\hline & $\mathrm{N}$ & 116 & 116 \\
\hline & $\begin{array}{l}\text { Std. } \\
\text { Deviation }\end{array}$ & .566 & .548 \\
\hline & Median & 3.00 & 3.00 \\
\hline \multirow[t]{4}{*}{ Total } & Mean & 3.39 & 3.40 \\
\hline & $\mathrm{N}$ & 215 & 215 \\
\hline & $\begin{array}{l}\text { Std. } \\
\text { Deviation }\end{array}$ & .601 & .586 \\
\hline & Median & 3.00 & 3.00 \\
\hline
\end{tabular}

(Table2):Demonstrate percentage of right foramen position in both gender

\begin{tabular}{|c|c|c|c|c|}
\hline \multicolumn{5}{|c|}{ Right mental foramen } \\
\hline \multirow{2}{*}{\multicolumn{2}{|c|}{$\begin{array}{l}\text { right mental foramen } \\
\text { position }\end{array}$}} & \multicolumn{2}{|c|}{ Gender } & \multirow{3}{*}{$\begin{array}{l}\text { Total } \\
1\end{array}$} \\
\hline & & \multirow{2}{*}{$\begin{array}{l}\text { male } \\
0\end{array}$} & \multirow{2}{*}{$\begin{array}{l}\text { female } \\
1\end{array}$} & \\
\hline 1 & Count & & & \\
\hline & $\begin{array}{l}\% \text { within } \\
\text { Gender }\end{array}$ & $0.0 \%$ & $0.9 \%$ & $0.5 \%$ \\
\hline \multirow[t]{2}{*}{2} & Count & 1 & 2 & 3 \\
\hline & $\begin{array}{l}\% \text { within } \\
\text { Gender }\end{array}$ & $1.0 \%$ & $1.7 \%$ & $1.4 \%$ \\
\hline \multirow[t]{2}{*}{3} & Count & 55 & 74 & 129 \\
\hline & $\begin{array}{l}\% \text { within } \\
\text { Gender }\end{array}$ & $55.6 \%$ & $63.8 \%$ & $60.0 \%$ \\
\hline \multirow[t]{2}{*}{4} & Count & 37 & 38 & 75 \\
\hline & $\begin{array}{l}\% \text { within } \\
\text { Gender }\end{array}$ & $37.4 \%$ & $32.8 \%$ & $34.9 \%$ \\
\hline \multirow[t]{2}{*}{5} & Count & 6 & 1 & 7 \\
\hline & $\begin{array}{l}\% \text { within } \\
\text { Gender }\end{array}$ & $6.1 \%$ & $0.9 \%$ & $3.3 \%$ \\
\hline \multirow[t]{2}{*}{ Total } & Count & 99 & 116 & 215 \\
\hline & $\begin{array}{l}\% \text { within } \\
\text { Gender }\end{array}$ & $100.0 \%$ & $100.0 \%$ & $100.0 \%$ \\
\hline
\end{tabular}

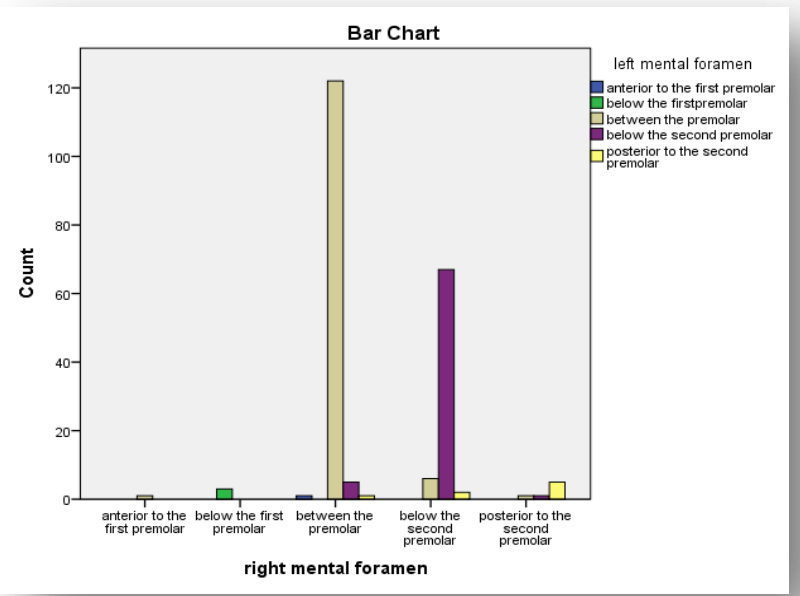

(Chart1):Demonstrate percentage of right mental foramen position in both gender 
(Table 3): Demonstrate percentage of left mental foramen position in both gender

\begin{tabular}{|c|c|c|c|c|}
\hline \multicolumn{5}{|c|}{ left mental foramen } \\
\hline \multirow{2}{*}{\multicolumn{2}{|c|}{ left mental foramen position }} & \multicolumn{2}{|c|}{ Gender } & \multirow{3}{*}{$\begin{array}{r}\text { Total } \\
\\
1\end{array}$} \\
\hline & & male & female & \\
\hline \multirow[t]{2}{*}{1} & Count & 0 & 1 & \\
\hline & $\%$ of Total & $0.0 \%$ & $0.5 \%$ & $0.5 \%$ \\
\hline \multirow[t]{2}{*}{2} & Count & 1 & 2 & 3 \\
\hline & $\%$ of Total & $0.5 \%$ & $0.9 \%$ & $1.4 \%$ \\
\hline \multirow[t]{2}{*}{3} & Count & 58 & 72 & 130 \\
\hline & $\%$ of Total & $27.0 \%$ & $33.5 \%$ & $60.5 \%$ \\
\hline \multirow[t]{2}{*}{4} & Count & 34 & 39 & 73 \\
\hline & $\%$ of Total & $15.8 \%$ & $18.1 \%$ & $34.0 \%$ \\
\hline \multirow[t]{2}{*}{5} & Count & 6 & 2 & 8 \\
\hline & $\%$ of Total & $2.8 \%$ & $0.9 \%$ & $3.7 \%$ \\
\hline \multirow[t]{2}{*}{ Total } & Count & 99 & 116 & 215 \\
\hline & $\%$ of Total & $46.0 \%$ & $54.0 \%$ & $100.0 \%$ \\
\hline
\end{tabular}

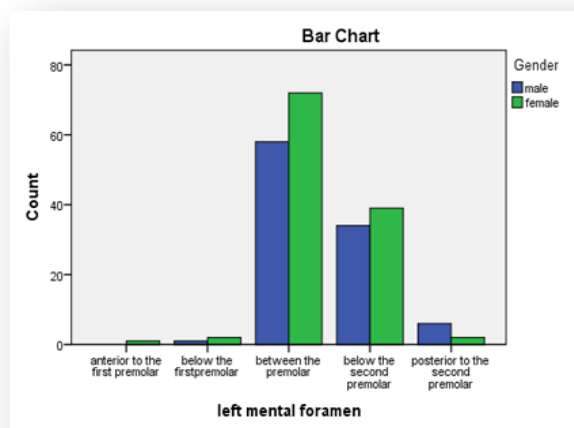

(Chart 2):Demonstrate percentage of left mental foramen position in both gender

(Table 4):Demonstrate right \&left mental foramen positioning percentage.

\begin{tabular}{|c|c|c|c|c|c|c|c|}
\hline \multicolumn{8}{|c|}{ right mental foramen * left mental foramen } \\
\hline \multirow{2}{*}{\multicolumn{2}{|c|}{ right mental foramen }} & \multicolumn{5}{|c|}{ left mental foramen } & \multirow{3}{*}{$\begin{array}{l}\text { Total } \\
1\end{array}$} \\
\hline & & 1 & 2 & 3 & 4 & 5 & \\
\hline \multirow[t]{2}{*}{1} & Count & 0 & 0 & 1 & 0 & 0 & \\
\hline & $\%$ of Total & $0.0 \%$ & $0.0 \%$ & $0.5 \%$ & $0.0 \%$ & $0.0 \%$ & $0.5 \%$ \\
\hline \multirow[t]{2}{*}{2} & Count & 0 & 3 & 0 & 0 & 0 & 3 \\
\hline & $\%$ of Total & $0.0 \%$ & $1.4 \%$ & $0.0 \%$ & $0.0 \%$ & $0.0 \%$ & $1.4 \%$ \\
\hline \multirow[t]{2}{*}{3} & Count & 1 & 0 & 122 & 5 & 1 & 129 \\
\hline & $\%$ of Total & $0.5 \%$ & $0.0 \%$ & $56.7 \%$ & $2.3 \%$ & $0.5 \%$ & $60.0 \%$ \\
\hline \multirow[t]{2}{*}{4} & Count & 0 & 0 & 6 & 67 & 2 & 75 \\
\hline & $\%$ of Total & $0.0 \%$ & $0.0 \%$ & $2.8 \%$ & $31.2 \%$ & $0.9 \%$ & $34.9 \%$ \\
\hline \multirow[t]{2}{*}{5} & Count & 0 & 0 & 1 & 1 & 5 & 7 \\
\hline & $\%$ of Total & $0.0 \%$ & $0.0 \%$ & $0.5 \%$ & $0.5 \%$ & $2.3 \%$ & $3.3 \%$ \\
\hline \multirow[t]{2}{*}{ Total } & Count & 1 & 3 & 130 & 73 & 8 & 215 \\
\hline & $\%$ of Total & $0.5 \%$ & $1.4 \%$ & $60.5 \%$ & $34.0 \%$ & $3.7 \%$ & $100.0 \%$ \\
\hline
\end{tabular}




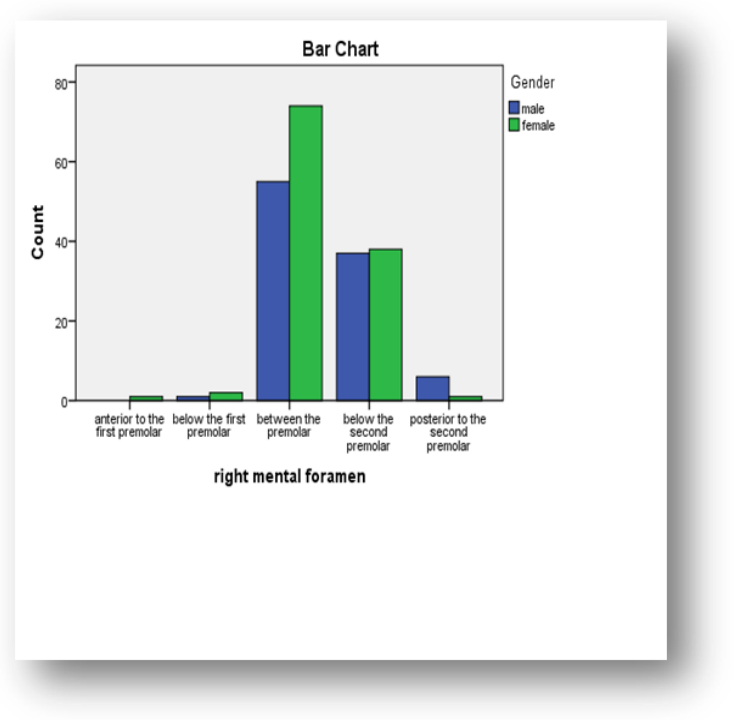

(chart 3):Demonstrate right \&left mental foramen positioning percentage

\section{DISCUSSION}

Mental foramen is considered an imperative anatomical landmark, the position of which assists surgical, local anesthetic, and other invasive procedures for maxillofacial surgeries. Its location should be taken into account before any surgery in this region to avoid any injury to the neurovascular bundles passing through these foramina. Occasionally, mental foramen is misdiagnosed as a radiolucent lesion situated in the apical area of the mandibular premolar teeth. Therefore, knowledge of accurate anatomical position of mental foramen is of paramount importance in periodontal surgery or flap surgery, especially in mandibular premolars, surgical orthodontics, and retrograde amalgam fillings ${ }^{(15)}$. There are significant differences reported in the location of MF among different ethnic groups Igbigbi and Lebona (16) in Malawians and Mbajiorgu et al. (17) in Zimbabweans mandibles reported position IV as the commonest followed by position V; however, Santini and Land ${ }^{(18)}$ in British and Green ${ }^{(19)}$ in Chinese mandibles observed position III being the commonest followed by position IV. In other studies Ngeow and Y. Yuzawati ${ }^{(20)}$ in Malay populations found the most common position was IV followed by position III, AL-SHAYYAB et al found that The most common horizontal location and shape of the mental foramen on panoramic image in Iraqi population are between the two premolars ${ }^{(23)}$, in our study The most common position was found position III followed by position IV, so we agree with Santini and Land in British and Green in Chinese ALSHAYYAB et al, and disagree with Igbigbi and Lebona in Malawians, Mbajiorgu et al. in Zimbabweans mandibles and Ngeow and Y. Yuzawati in Malay population. Variability in MF position may be related to different feeding habits subsequently affecting mandibular development ${ }^{(21)}$. Prior knowledge of common positions in local populations may be helpful in effective nerve blocks and surgeries in those regions. Thus, the position of the mental foramen attributes to variations in different population.

\section{Conclusion}

The most common location was reported to be between the two premolars, with a definite bilateral symmetry on both left and right sides. No gender preferences were observed.

\section{References}

1. S. Boopathi, S. Chakravarthy Marx, S. Dhalapathy, and S. Anupa, "Anthropometric analysis of the infraorbital foramen in a south indian population," Singapore Medical Journal, vol. 51, no. 9, pp. 730-735, 2010.

2. J. Iwanaga, K. Watanabe, T. Saga et al., "Accessory mental foramina and nerves: Application to periodontal, periapical, and implant surgery," Clinical Anatomy, vol. 29, no. 4, pp. 493-501, 2016.

3. M. Lipski, I. M. Tomaszewska, W. Lipska, G. J. Lis, and K. A. Tomaszewski, "The mandible and its foramen: Anatomy, anthropology, embryology and resulting clinical implications," Folia Morphologica (Poland), vol. 72, no. 4, pp. 285-292, 2013.

4. I. Roa Henrí?quez and O. Arriagada, "Anatomical variations of Mandibular canal with clinical significance. Case Report," International Journal of Morphology, vol. 33, no. 3, pp. 971-974, 2015.

5. F. M. Fabian, "Position, shape and direction of opening of the mental foramen in dry mandibles of Tanzanian adult black males," Italian Journal of Anatomy and Embryology, vol. 112, no. 3, pp. 169-177, 2007.

6. G. Greenstein and D. Tarnow, "The mental foramen and nerve: clinical and anatomical factors related to dental implant placement: a literature review," Journal of Periodontology, vol. 77, no. 12, pp. 1933-1943, 2006.

7. D. V. Kuzmanovic, A. G. T. Payne, J. A. Kieser, and G. J. Dias, "Anterior loop of the mental nerve: A morphological 
and radiographic study," Clinical Oral Implants Research, vol. 14, no. 4, pp. 464-471, 2003.

8. M. González-Martín, D. Torres-Lagares, J. L. GutiérrezPérez, and J. J. Segura-Egea, "Inferior alveolar nerve paresthesia after overfilling of endodontic sealer into the mandibular canal," Journal of Endodontics, vol. 36, no. 8, pp. 1419-1421, 2010. ○ 1. Mahima VG. Mental foramen for gender determination:

9. a panoramic radiographic study. Medico-Legal Update 2009;9(2):33-35

10. Naroor N, Shenai P, Chatra L, Veena KM, Rao PK, Shetty P. Gender determination using the mental foramen. J Cranio Max Dis 2015 Jul;4(2):144-147.

11. Parnami P, Gupta D, Arora V, Bhalla S, Kumar A, Malik R. Assessment of horizontal and vertical position of mental foramen in Indian population in terms of age \& sex in dentate subjects by panoramic radiographs: a retrospective study with review of literature. Open Dent J 2015 Jul;9(2):297-302.

12. Ilayperuma I, Nanayakkara G, Palahepitiya N. Morphometric analysis of the mental foramen in adult Sri Lankan mandibles. Int J Morphol 2009 Dec;27(4):10191024.

13. Al Jasser NM, Nwoku AL. Radiographic study of mental foramen in a selected Saudi Population. Dentomaxillofac Radiol 1998 Nov;27(6):341-343.

14. Haghanifar S, Rokouei M. Radiographic evaluation of the mental foramen in a selected Iranian population. Indian J Dent Res 2009 Apr-Jun;20(2):150-152.

15. Moogala S, Sanivarapu S, Boyapati R, Devulapalli NS, Chakrapani S, Kolaparthy L. Anthropometrics of mental foramen in dry dentate and edentulous mandibles in Coastal Andhra population of Andhra Pradesh State. J Indian Soc Periodontol 2014 Jul;18(4):497-502

16. P. S. Igbigbi and S. Lebona, "The position and dimensions of the mental foramen in adult Malawian mandibles," West African Journal of Medicine, vol. 24, no. 3, pp. 184-189, 2005.

17. E. F. Mbajiorgu, G. Mawera, S. A. Asala, and S. Zivanovic, "Position of the mental foramen in adult Black Zimbabwean mandibles: a clinical anatomical study," Central African Journal of Medicine, vol. 44, no. 2, pp. 24-30, 1998.

18. A. Santini and M. Land, "A comparison of the position of the mental foramen in Chinese and British mandibles," Acta Anatomica, vol. 137, no. 3, pp. 208-212, 1990.

19. R. M. Green, "The position of the mental foramen: a comparison between the southern (Hong Kong) Chinese and other ethnic and racial groups," Oral Surgery, Oral Medicine, Oral Pathology, vol. 63, no. 3, pp. 287-290, 1987.

20. W. C. Ngeow and Y. Yuzawati, "The location of the mental foramen in a selected Malay population.," Journal of Oral Science, vol. 45, no. 3, pp. 171-175, 2003.
21. H. Yeşilyurt, A. Aydinlioğlu, A. Kavakli et al., "Local differences in the position of the mental foramen," Folia Morphologica, vol. 67, no. 1, pp. 32-35, 2008.

22. Jasser N M A L Nwoku. Morphometrical and morphological study of mental foramen in dry dentulous mandibles of South Andhra population of India. Dentomaxillofac. Radiol.1998; 27 :341.

23. Mohammad H. Al-Shayyab*; Firas Alsoleihat**; Najla S. Dar-Odeh* ; Soukaina Ryalat* \& Zaid H. Baqain The Mental Foramen I: Radiographic Study of the AnteriorPosterior Position and Shape in Iraqi PopulationInt. J. Morphol., 33(1):149-157, 2015 